\title{
World Renowned Ancient Hindu Vedas - A Brief Appraisal of the Scriptures for Common Man Across the Globe
}

\author{
Adhikarla Suryanarayana Rao \\ Department of Biotechnology, Bharathidasan University, Tiruchirappalli, India \\ Email address: \\ asraobio@gmail.com

\section{To cite this article:} \\ Adhikarla Suryanarayana Rao. World Renowned Ancient Hindu Vedas - A Brief Appraisal of the Scriptures for Common Man Across the \\ Globe. International Journal of Literature and Arts. Vol. 9, No. 1, 2021, pp. 15-21. doi: 10.11648/j.ijla.20210901.13
}

Received: January 9, 2021; Accepted: January 20, 2021; Published: January 25, 2021

\begin{abstract}
Manuscript write up and appraisal is based exclusively on the monumental 22 volumes compilation of four Vedas -ancient, globally acknowledged Hindu scriptures. As per the references quoted, the four Vedas Viz; Rigveda, Yajur Veda, Sama Veda and Atharva Veda has in all 10,589, 1975, 1875 and 5977 verses respectively cumulatively making 20,416 verses. This compilation does not include Upanishads which focus more on philosophy and spirituality. What is meant for scholars is not attempted for appraisal but only those points which can be easily understood by common men who constitute the vast majority of the society. Such subject matter does constitute a significant portion of the four Vedas. Manuscript emphasizes drastic pruning of repetitions of verses which convey the same meaning and thought to get a much shorter version of the compilation which can be easily read by more number of people and can also be easily translated into other languages. An important message of this manuscript is a significant portion Vedas proper deals with material world and material needs, desires and comforts of man --- food, shelter, health, wealth, wisdom, vigor, vitality, progeny, long life of hundred years, happiness, peace etc. For this God and many Deities and others are repeatedly invoked through rituals /sacrifices, prayers, praising the glories and attributes and chanting hymns. They are also prayed for spiritual development and attaining divine bliss and enlightenment. Though Vedas believe in one supreme, deification and polytheism is a characteristic feature of Vedic religion. Manuscript mentions specifically many deities invoked and their attributes and addresses, concept of twin divines, cardinal importance of fire and strong conviction and desire of people for punitive justice. Atharva Veda is unique and of modern relevance too as it prescribes many medicinal plants and other treatments for curing many ailments. Many parameters of day to day life and environment are mentioned in the Vedas.
\end{abstract}

Keywords: Four Vedas, Basic Philosophy, Bounties of Nature, Many Rituals, Repetitions of Verses, Material Needs \& Comforts, Punitive Justice, Medicinal Plants, Curing of Diseases, Divine Enlightenment

\section{Introduction and Background}

At the outset author wish to say that the present write up and appraisal is based exclusively on the 22 volumes compilation which gives the verses of the original text in Sanskrit along with English transliteration and translation [14]. Only English translations have been taken into account. The compilers and publishers are held in high esteem in India and are considered to be venerable authorities on the subject. For some additional comments some sites on Google and introductory part of the compilers have been referred to and mentioned in the text. [5-11].

Readers can refer to the links above to get a preliminary account and also proceed for further study.
Hindus - more correctly referred to as Sanatanis (meaning ancients) uphold Vedas as the source of true knowledge and which teaches all the ideals of human life to the entire mankind. Vedas are treated as primary authority and proof for the religion. The importance of this scripture cannot be overstated. Extremely rich vocabulary, rich messages \& thoughts, composition of verses and more so the tunes in which they are chanted by traditional priests and scholars are amazing keeping in view the time period in which Vedas were composed. How, over what period of time and who all are involved is a subject matter for scholars. Common man should not worry about this but ponder only on the contents. Faith and academic approach are entirely two different things. Suffice to say that at least Rig Veda is considered as the most 
ancient of all the scriptures in the world and it is the largest of all the four Vedas (see caption 2.). So many scholars across the world have acknowledged so. Ancient tradition of preserving this entire knowledge by oral tradition is still continuing in India by the clergy and disciples in religious organizations. It is so with the other three Vedas.

A large number of western and Indian scholars have been greatly influenced and they have been duly mentioned and acknowledged by the compilers in their introductory part. Key figures who are most involved and have direct involvement in translations are mentioned Viz; Ralph T. H. Griffith, Horace Hayman Wilson, Dwight Whitney, Max Muller and Dayananda Saraswati [12-16]. In addition to the above some more western scholars acknowledged are; Aldous Huxley, Alfred North Whitehead, Arnold J Toynbee, Arthur Schopenhauer, Francois Voltaire, Rudolf Steiner, Wilhelm von Humboldt and Will Durant [17]. An important aspect of the 22 volume compilation is they constitute only the "Vedas proper" [1-4]. They do not include "Texts of Upanishads" which are commonly referred to as Vedanta (meaning end /at the end of the Vedas) and are considered very much as a part of Vedas - different Upanishads forming part of different Vedas. (English translation given for Upanishad is, "sit down closely" as one would to listen attentively to instruction by a teacher or other authority figure, or to mean "secret teaching" or "revealing underlying truth"). These are the texts discussing meditation, philosophy and spiritual knowledge. For reasons known only to the compilers only one very short Upanishad Isaavaasyopanishad or Isopanishad of just 19 verses in Yajur Veda (Volume III chapter 40) and a cryptic Upanishad of six verses-Sivasankalpa Upanishad-(Volume III chapter 34) is mentioned The subject matter of Upanishads is more related to spirituality and spiritual development while Vedas proper cover a broad range of topics and mentions so many things of the day to day life. The total number of Upanishads and the number of Upanishads that really form part of Vedas and those that do not form a part of Vedas is a subject matter for scholars and common man should not worry about it. The advise for them is to stick initially to those where there is no dispute in case they want to study philosophy and spirituality.

As Hinduism is viewed by everyone as highly Polytheistic and as there exists an enormous amount of authoritative texts in addition to Vedas and numerous saints have preached little differently -in spite of acknowledging the primary authority of Vedas, it is essential to know the compilers viewpoint which is as follows: "Certain fundamentals which constitute philosophy of entire Vedas are a) Though so many are addressed as divine and their relationship with supreme Lord is praised, one Supreme reality -First Lord or Lord Supreme -is acknowledged who has the standard three attributes of supreme/almighty Viz; Omnipotent; Omniscient; Omnipresent. HE is considered as the source of power for other Gods and to humans. b). The world is real, meaningful, orderly, and purposeful. b) Our life is meaningful and purposeful, a continuous one a cycle of births \& deaths with another cycle of bondage and liberation. [1-4]. "(Belief in rebirth and several rebirths is a basic tenet of Hindu philosophy which is not there in Abrahamic religions).

\section{Organization and Structure of the Four Vedas}

As per DAV Publication Division all four Vedas constitute 22 volumes [1-4]. As mentioned above this is considered as a standard and authoritative compilation. Rig Veda, Sama Veda, Yajur Veda and Atharva Veda comprising 12, 2, 3 and 5 Volumes respectively. However, it should be noted that, though every first volume of every Veda has some introductory part, the whole volume one of Rig Veda is devoted to a broad and comprehensive introduction along with index. Hence, the Verses of Rig Veda start from the volume two of this compilation. In addition to the term volume the compilers have also referred to the term "Book". However, because of introductory volume one and some clubbing of subsequent volumes the Book number and the volume number does not exactly match. Hence, the organization of Rig Veda as per these compilers and publisher is as follows: Book I (Vol II \& III) has 191 hymns (1-121 (Vol II) \& 122-191 (Vol III); Book II- 1-43 hymns and Book III- -1-62 hymns together constituting Volume IV; Book IV- 1-58 hymns and Book V- -1-87 hymns together constituting Volume V; Book VI (Volume IV) 1-75 hymns; Book VII (Volume VII) -1-104 hymns; Book VIII (Volume VIII \& Volume IX) 1-40 hymns (Volume VIII) \& 41-103 hymns (Volume IX); Book IX (Volume X) 1-114 hymns; Book 10-1-86 hymns and $87-191$ hymns together constituting Volume XI \& Volume XII) respectively).

As per the compilers Rigveda, Yajur Veda, Sama Veda and Atharva Veda has in all 10,589; 1975 verses 1875 and 5977 verses respectively [1-4]. However, most important point to be noted is that, out of 1,875 verses in Sama Veda only 75 are unique to Sama Veda while the bulk --1800- are repetitions of Rigvedic verses (Verses unique to Sam Veda have been mentioned by the compilers in the introductory part of Sama Veda, Volume 1-page 38 \& 39 with a note that the number unique to Sama Veda can range from 70-80). So the total verses of all four Vedas -including Sama Veda repetitionscomes to 20,416. Thus, Rig Veda, Yajur Veda, Sama Veda and Atharvaveda approximately constitute $51.86 \%, 9.67 \%, 9.18 \%$ and $29.27 \%$ respectively. If only 75 verses are considered as in Samaveda-ignoring the repetitions --then the total verses in all four Vedas would be reduced to 18.616 verses in which case Rig Veda, Yajur Veda, Sama Veda and Atharva Veda constitute approximately $56.88 \%, 10.60 \%, 0.4 \%$ and $32.10 \%$ respectively. Slight variations from the above may be found with some other compilations and have been referred to by the compilers in their introductory part of the Vedas [1-4]. About "repetitions" another point to be noted is in addition to those which have been specifically mentioned above about Sama Veda, repetitions do occur in other Vedas also. They can be repetitions of verses of one Veda in another Veda or repetitions can be there even in the same Veda. Such 
repetitions have been mentioned by the compiler while describing the verses. It has also been mentioned by the compilers that Atharva Veda as the fourth Veda was added much later. Rigveda as mentioned above is the oldest and the largest of the all. Hence, it covers a lot which is included even in other Vedas. As mentioned above Rig Veda alone constitutes more than half of the total Vedas. The unique features of other Vedas have been mentioned in the text.

\section{What the Present Manuscript Highlights/Emphasizes}

One should understand the task and limitations of presenting 22 volumes in a single article! How can one appraise 22 volumes in a single article!? What is meant for scholars is not attempted for appraisal here but only those points which can be easily understood by common men. who constitute the vast majority of the society. And such subject matter constitutes a significant bulk of Vedas. By common men, it is not meant uneducated/illiterate alone but even highly or less educated. Because, they cannot be scholars in Sanskrit or English or in other languages in which Vedas are available. Secondly, even if one knows one may not be able to devote so much time to go through the bulk. Above all, not everyone-but rather only a few will be deeply interested in philosophy and spiritual aspects and take this as a whole time profession. Further, many texts other than Vedas are available for people to study philosophy. But all the above categories can understand certain things. Such things as mentioned above do constitute a significant bulk of the four Vedas and it is these things that are appraised in this manuscript. Though the compilers -and others too--mention about so many repetitions, what apparently has not been / is not mentioned or highlighted -which the present manuscript highlights --is the large number of repetitions of verses which convey the same meaning and thought. It is these that the present manuscript highlights and brings to the greater attention of everyone. If this pruning -that is pruning of large number of repetitions of verses which convey the same meaning and thought in addition to the large number of repetitions admitted by the compilers--- can be done by a scholar, a much shorter composition can be provided without any distortion of the essence. A shorter version can be read by more number of people and can also be easily translated into other languages. This is another important point/message that this manuscript wants to emphasize. Yet another important point which the manuscript wants to emphasizes is that a significant portion of the above 22 volumes -Vedas proper--deals with material world and material needs, desires and comforts of man.

\section{Who Are All Invoked}

In addition to the Supreme Lord so many Deities are invoked. Deification of both animate and inanimate things is an important characteristic feature of Hinduism. In a nut shell, all the celestial and terrestrial forces/components and all those which are needed and on which man depends are invoked. To mention some: Bounties of nature -sun, ocean, fire, lightning, clouds, wind, rain, water, earth, mid-space, sky, moon, stars, night, mountains. Further, preceptors, pair of twin divines, self/ soul, soma (Elixir), heaven and breath. By and large the above are invoked. For all the above Divinity is attributed and all praises and glories of the Divine may be attributed. Homage/ Worship/ Prayer/Rituals/Chanting hymns etc maybe performed to all.

\subsection{Who Are Referred to as Twin Divines or Pairs of Twin Divines}

In day to day discussions, Twin divines (Ashwins) are considered as divine physicians - Gods of health and medicine. However, the Vedas describe many other "Pairs of Deities" also as Twin divines-For example -Heaven \& Earth; Cosmic Vitality \& Consciousness; Light \& Life; Day \& Night; Lord of Terrestrial \& Celestial forces; Sun \& Fire; Sun \& Ocean; Sun \& Wind; Fuel \& Energy; Resplendent Lord \& Rain Lord; Mind \& Speech; Air-\& Sun; Lord of Celestial forces \& Fire God; Friendly Lord \& Rain Lord; etc. Same deity /lord can be addressed with more than one attribute. Hence, English translations for the same Sanskrit term can be different.

\subsection{Attributes and Addressing of God/Deities}

Hinduism believes that glories of Lord / almighty are indescribable and inexhaustible. The translators have used numerous attributes while addressing different Gods/ Deities [1-4]. Few of them are: The one supreme Lord is addressed by many names and praised-Creator, Sustainer \& Protector; Lord of wealth; Lord of Heaven; Resplendent; Bestower of: Food, Progeny; Natures Gifts; Plants both for food and medicines; Bliss and Enlightenment; Happiness and Sustenenance. Illuminating; Source of intellect; Source of Vigor, Vitality, Wisdom \& Energy and Excitement and Prosperity; Great observer \& Scrutinizer; Adorable; Ordainer; Gracious; Nurturing; Impeller; True Friend; Great; Powerful; Sagacious; Universal; Ultimate; Bounteous; Venerable; In addition to God many deities also are addressed as above. Further, soul also is prayed in all ways and attributes of God are given to soul also. (Note - In addition to the above attributes other attributes and addresses are reflected in various boons and gifts which devotees seek from the Lord/God and other deities and natures bounties and all items needed/ desired by the devotees etc (See Caption 10)

\subsection{Why Fire Is Praised So Much}

A popular age old practice of Hinduism is to conduct rituals /sacrifices where all libations and oblations are put into the sacrificial fire and the invokers/ devotees/ worshippers expect the fire to carry the offerings to the supreme or to the desired ends who are in turn controlled by supreme. Hence, fire is immensely praised and is treated /viewed on par with the Supreme Lord and equal credit is 
given to the Fire for bestowing any benefit. In fact Fire is invoked for everything. Therefore, Glories of Supreme Lord are also attributed to Fire divine. In particular Yajurveda predominantly consists of sacred hymns for performing. many rituals/ sacrifices for householders, kings, businessmen for fulfilling their various desires and hymns for atonements and for construction of altar (raised structure or place on which sacrifices are offered or incense is burned in worship) or hearths (the area around a fire place or the area of floor in front of it) for various rituals and sacrifices. (see Caption 10)

\subsection{Mention of Many Parameters of Day to Day Life}

Vedas mention about: different seasons; man's basic emotions; agricultural implements and weapons of those times; numerous animals; family relationships; different occupations; many sages; human body parts -both external and internal; different food items and beverages; Further, mention of Galaxies and Planets also is made.

\section{Punitive Justice for Enemies}

It is really strange that even in ancient times people strongly wanted punitive justice for enemies. Vedas strongly believe in it. They wanted absolutely no mercy and no forgiving-rather strong retaliation -for enemies and for this they were even fervently invoking God/Deities repeatedly. This aspect constitutes one significant portion of the Vedas. Only briefly how God/deities are invoked in this regard is mentioned below:

Drive the wealth of our enemies; weaken our enemies; Destroy and crush our enemies; May you chop off their heads; Destroy the wicked, evil persons and our enemies; May we conquer our rivals; Let the doer of detestable deeds be doomed to death; Blow away/burn/ subdue all our haters and enemies and whom all we hate. Destroy the enemies fleeing in different directions; Destroy the mind and plans of the enemies; Take away their force and make my rivals speech defunct; O Epidemic destroy our enemies; Kill the defaulter (who do not pay our dues). May the enemies not paying our dues run away helter-shelter; may you snatch away the wealth of our enemies.; drive away the treacherous; Kill the enemies and divide their booty among us; May the Lord burn him who behaves like an enemy; May those who attack us from any side suffer pain; May the thinking power of our enemies be lost; Subdue the arrogance of our enemies; Make all those with evil eye and designs on us become weaponless; Lower their rank and prestige and defeat them; May you subjugate every person who wish to harm us and crush everyone who wants to rule over us; Drive away our rivals who are born and prevent those who are yet to be born; Whoever tries to curse or abuse us in any circumstance may be destroyed; Destroy the energy of our adversaries. Destroy his progeny also; Let the tormentor not get any food. Let a flesh eater eat him; May they not have a home nor a child; Crush the evil and Evil Doers; Kill those who wish to rob our wealth. Destroy him/those who want to destroy me/us; Drive away the selfish and wicked people; May water and medicinal herbs be friendly to us but unfriendly to our enemies.

\section{Purpose of Invocation}

Why the Supreme Lord and Many Deities are invoked or worshipped /or rituals \& sacrifices performed offering oblations and libations? God and Deities and others are repeatedly invoked through rituals /sacrifices/worshipping/prayers / Praising the glories and different attributes/Chanting hymns. Primary purpose of invoking -numerous times and in different words--is almost always to gain material benefits and destruction of enemies $\&$ opponents. A very significant portion of the Vedas comprise of the above. However, during this process very few times devotees did pray for spiritual benefits. As per Hinduism the ultimate purpose of human life is to attain salvation / liberation/ God realization/ Self realization and freedom from repeated cycle of births and deaths. These are emphasized in several other Hindu philosophical texts and which is also a matter of day to day discussion among the followers of Hinduism. (Hindus unlike Abrahamic religions believe in rebirth and multiple rebirths till salvation is achieved). However, as mentioned above very less mention in this regard while seeking material benefits and praying for punitive justice. Even otherwise the above philosophical/spiritual aspects are discussed / focused in Upanishads portion. The compilation of 22 volumes on which the present write up is based does not include Upanishads except for the one that is mentioned above [1-4]. In any case it can be said that a good portion of the Vedas deal with people longing for material benefits, self upliftment and destruction of enemies /opponents.

People prayed numerous times - both orally and by rituals for: food, wealth, wisdom, vigor, vitality, progeny, long life (long life is described in more than one way-as hundred years, hundred autumns, hundred springs etc); protection and well being; destroying evils affecting; fulfilling virtuous desires and aspirations not only of theirs but also of their descendents; protection from enemies, exploiters, cruel creatures, crooked and tyrannical people and evil forces; making themselves illustrious and talented; preventing them from committing any sins; not having any negative consequences for their actions; guiding on the right path; guiding in struggles; protection from any sin; remaining devoted to parents; tiding over troubles and miseries; removing the weakness of body, mind and intellect; numerous horses, cattle and brave sons with assured pasture / food for them.

Excellent and comfortable shelter which cannot be damaged by any natural disasters; fame, good fortune; protecting from oppressors; totally eliminating all hardships and grant all enjoyments; excelling others; to protect from natural forces; removing grief and miseries; totally destroying enemies and wicked; overcoming all the evils and miseries that come across; . ensuring victory in battles; virtuous offspring and their prosperity \& happiness; 
bestowing brave, heroic \& disciplined progeny to perpetuate the race and proficient in scriptures and become one among the enlightened ones;; bestowing social status; bestowing numerous \& continuous supply of high milk yielding cows, cattle, swift horses and brown mares, bulls and sheep; bestowing robust oxen for agriculture;. golden treasures, leading beyond danger \& affliction; protection from disease of all the external and internal parts; destroying old age; protection of families, cattle and plants; enabling to do great and noble deeds. removing all sins; saving from all distress; protection of warriors and protection of weak people; to give abundant water; to protect us from lawlessness; protecting the country and make it strong; restoring health to sick and old people; bestowing gifts which no one can take away; enabling the devotee to cultivate the soil; blessing barren women with progeny; protection of weak men, widows.

Destroying ignorance and wayward thoughts; bestowing gold and jewelry; destroying ignorance and make the senses function; destroying the progeny of our enemies who want to rob us; bestow riches and protect our riches from getting robbed; bestowing safety; bestowing all worldly pressure; To free us from all bondages inherited from our ancestors; to not to punish us if we violate your laws out of ignorance; to liberate us from sin; to bestow all worldly pleasures; granting strength to themselves, their sons and grand sons and longevity to all; protecting the crops and granaries; protecting valuable medicinal herbs and make use of medicinal plants; destroying all our adversities; removing all kinds of famine.

Though Soma is specifically invoked for curing all our ailments and heal all our diseases it is also invoked for some of the above mentioned.

Bestowing lasting competence of sense organs; power and glory; safety, peace and happiness; atoning our sins; making respectable in the society; purifying speech and mind; restoring what all we have lost; protecting body, mind \& soul protection from diseases by the medicinal herbs; for agriculture and well being; to destroy pests; grant gold, horses and cows; Ensuring items used for food, oblations \& libations; freeing from blemishes; victory in conflicts and over enemies; leading safely on all paths.

Security \& fearlessness both from friends and enemies; guarding from all sides and not succumbing to any vice; not being at the mercy of others; old age to be peaceful; Protection from weapons coming from all sides; removing ignorance; protection my breath and from death;. Removing any disability of any organ and function; granting success in procreation; overcoming all obstacles and dangers and with strength.

As mentioned above this aspect constitutes a significant portion of the Vedas put together and the above feelings have been expressed umpteen number of times in different words in all Vedas. What is mentioned in the manuscript is only a very brief appraisal. In the midst of the numerous material things that are solicited a few pertaining to spiritual development also have been prayed for: strong sense organs which can understand the supreme knowledge; guiding in search of truth; realizing the existence of God within oneself; continuously composing new hymns for the Lord/Deities; bestowing heavenly happiness and make qualified to experience immortal bliss; divine bliss or Divine enlightenment.

In a nutshell people wanted to bless them in all ways and always, soliciting everything that satisfying all their needs, desires and aspirations of this world and the other world.

\section{What Is Soma (Sanskrit Term with Multiple Meanings as Mentioned Below)}

Sama veda -- Shortest of all Vedas as mentioned above. "The verses are put into musical chants by the earliest human race and are popularly known as Saamans/Samans and the entire collection being referred to as Sama Veda". (But as mentioned above remember that of the 1875 verses only 75 are unique to Samaveda. So the musical chants may be said to refer as much to Rigveda. Even otherwise verses in other Vedas also are recited in different tunes by the clergy). It is very essential to distinguish the words "Soma" and "Saama/Sama" and different meanings of the word "Soma": a) "By invoking the supreme reality in the Saaman tunes (aloud or in silence) one experiences a peculiar trance in which one oozes out an indescribable fluid of spiritual exhilaration. In this state of consciousness, one forgets every other celestial and start invoking the above fluid which is termed "Soma" -Hence, Soma is a fluid of conceptual experience, a personification of what is known as truth, light and immunity. The above experience cannot be described but has to be experienced and enjoyed and tasted. Hence, one should differentiate this experience with the baser experience of consuming alcoholic beverages called "Suraa". Saama Veda verses sing the glory of this conceptually flowing Soma-the "Soma Pavamaana" entire book Book 9 (Volume 10 of 141 verses -) of Rigveda is devoted to this "Soma Pavamaana". Soma after being subjected to different treatments-referred to as curing-- and the final juice is called 'Soma Pavamaana". Hence, the term Soma Veda also comes into usage for Saama Veda b) Different colors are attributed to Soma. Further, the recipient wants to dilute this conceptual elixir with water or milk or honey. or filtered through wooden sieves or filters and collected in receivers and then diluted with water, milk and finally mixed with curds and honey and then enjoyed. The above are considered as anthropomorphic/ metaphorical expressions. c)" Soma" also refers to a medicinal herb-a creeper supposed to be on the top of the hills like Himalayas and which can cure ailments of many types and even all types [18-20]. Though a specific herb has been referred to the content of soma is supposed to be present in all medicinal plants d) Soma also refers to Moon. In fact the weeks of the day are referred with respect to planets and Monday in Indian and some other languages refers to the day of Moon. 


\section{Curing of Diseases and Medicinal Plants}

Atharva is also a synonym for "bhesaja" which means medicine and therefore Atharva Veda is also called as Bhesaja veda. Or the "Science of Medicine". Further, a point to be noted is mention of medicinal plants is there in other Vedas too. Hence, even medicinal plants are praised in Vedas.

Herbal system of medicine in India is ancient and even now is world renowned. Though mention of medicinal plants are there in all Vedas, Atharva Veda deals with it particularly. Further it also describes to a little extent the morphology of the medicinal plants which were in use. Atharva is also a synonym for "Bhesaja" which means medicine and therefore it is also called as Bhesaja Veda. Or the "Science of Medicine". In addition ot Vedas other important works related to ancient herbal medicine are Sushruta Samhita and Charaka Samhita. Cumulatively all the above mention more than 700 medicinal plants [20-25]. No attempt has been made here to mention the names of the plant in Sanskrit and their corresponding Botanical names which is best left to specialists in Sanskrit and Taxonomy. However, a few major diseases and their mode of cure and few botanical names are mentioned here. Curing/ remedy involves not only plants but also animals, metals (primarily Lead), Phototherapy (sunlight treatment) and water therapy (water from some rivers and mountains). Further, invoking deities and even invoking the herbs themselves is also prescribed. Medicinal plants/ Herbal Medicines were used for curing / the treatment of leprosy, skin diseases, rheumatism, mental depression/problems lumbago, joint pains \& arthritis, broken bones, pleurisy, plague, infectious diseases, polio, blood cancer, hereditary diseases, diseases caused by germs, dysentery, hemorrhage, antidotes for snake bites (snake poison), removal of pain and poison of scorpion bites, strength, virility/rejuvenation / erectile dysfunction/ aphrodisiacs, Tuberculosis, Haemorroids \& pathological growths of body, peptic ulcers, infertility, begetting male progeny. Maintaining proper breath and good vision, all types of fever and wasting diseases, overcoming the effects of sorcery, and even for longevity. A few major plants are as follows: Soma Plant (Sarcostemma species or Ephedra species) for more than one reason is considered as the King of plants or Lord of the forest. Next to this in importance seems to be Jangida/Jangida mani plant with a wide range of curative properties (likely botanical name being Terminalia arjuna) [26]. Other important plants include: Clypea hernadifolia; Hemionitis cordifolia; Acorus calamus; Achyranthes aspera; Poa cyanosuroides; Flacourtis sapida; Craetva roxburghii; Butea frondosa; Ficus religiosa (this is important from the religious point of view also.); Prosopis spicigera; Acacia catechu; Odita Pinnata; Blyxa octandra; Ficus Benghalensis; Commiphora wightii; Costus speciousus; Mimosa suma; Eleusina indica; Ficus glomerata etc Common crop plants also were used for treatment like rice, barley, sesamum, sugarcane white and yellow mustard, some common grasses. Preparations from horn of a deer is considered of medicinal value to drive away hereditary diseases. It is recommended to observe animals like Boar, Mungoose, serpents, sparrows, eagles, deer etc visiting plants as these plants are supposed to be of medicinal value.

\section{Family Matters and Marital Happiness}

Being an ancient primary religious scripture many may find strange mention of certain things related to marriage, women's rights, love, sex, erotic descriptions, virility, awareness and importance of manly potency, herbs for rejuvenation (aphrodisiacs), marital happiness, mention of private parts and child birth details etc.

Marriage as an institution is there even in Vedic times. Women seems to have a right to chose her partner and widow marriage also was approved. The need for men to be virile and come up to the expectations of the women has been emphasized. Even in those days obsession for male children/progeny was there. Mention of deserted wives and men with forsaken wives also were there. Women fearing of other men and also other women leaning towards their husbands (rival wives) seems to be there. Both man and woman were highly possessive of their partners. Gambling was a potent evil and gamblers were strongly advised about the dire consequences of gambling (playing dice).

\section{Conclusions}

All the four Vedas are globally acknowledged as great ancient scriptures of Hinduism and in Hinduism are considered as primary authority. Even in the present modern times they are maintained by oral tradition reciting in different tunes. In the present form Vedas are too bulky. To enable large number of people-both in India and across the globe-- to read and to enable translations into other languages, there is a need to condense without sacrificing the essence. As to how it can be done has been mentioned and appraised in the manuscript. Major approach towards this endeavor is to eliminate the large number of repetitions conveying the same meaning and thought. Apart form the bulk of repetetiosn (approximately 96\% of verses of Rigveda in Samaveda, large number fo repetetions are also found in other three Vedas. They can be repetetions of verses of one veda in another Veda or repetetions even in the same Veda. Vedas proper (excluding Upanishads). are not texts dealing exclusively with philosophy \& spiritual matters but they do discuss a wide array of topics related to mundane world. These topics also are mentioned and appraised in the manuscript. They deal with many day to day affairs like family matters, different occupations and dealing with enemies. To say further in a nutshell. People used to solicit for everything they need for them and their progeny for a comfortable long life enjoying health, wealth, power and status and ultimately divine enlightenment In this regard, in addition to the supreme, many deities and other components of nature are invoked in every manner. In this context it is 
essential to know that though Vedas acknowledge and discuss polytheisma lot they strongly emphasize the concept of one supreme reality-First Lord or Lord Supreme. Hence, in addition to supreme so many deities are invoked and rituals performed. As oblations and libations are put into the fire during the rituals fire is praised as divine and on par with supreme. People of all categories -right from common man to king - used to perform rituals to fulfill their desires and aspirations. Medicinal plants and curing of many ailments mentioned in Vedas still attract the attention of present day academicians apart from details of other topics.

\section{References}

[1] Swami Satya Prakash Saraswati and Satyakam Vidyalankar (2011). Rig Veda, Volmes 1-12. D. A. V. Publication Division, New Delhi (India).

[2] Swami Satya Prakash saraswati and Satyakam Vidyalankar (2011). Sama Veda, Volmes 1 \& 2. D. A. V. Publication Division, New Delhi (India).

[3] Swami Satya Prakash saraswati and Uday Vir Viraj (2012). Atharva Veda, Volumes 1-5. D. A. V. Publication Division, New Delhi (India).

[4] Swami Satya Prakash Saraswati and Uday Vir Viraj (2012). Rigveda, Volmes 1-3. D. A. V. Publication Division, New Delhi (India).

[5] https://en.wikipedia.org/wiki/Rigveda - Rigveda (This page was last edited on 1 January 2021.

[6] https://en.wikipedia.org/wiki/Samaveda\# --Samaveda (This page was last edited on 27 December 2020,).

[7] https://en.wikipedia.org/wiki/Atharvaveda- Atharvaveda (This page was last edited on 28 December 2020.

[8] https://en.wikipedia.org/wiki/Yajurveda\# -- Yajurveda (This page was last edited on 22 December 2020,).

[9] https://en.wikipedia.org/wiki/Upanishads- Upanishads (This page was last edited on 13 December 2020).

[10] Joshua J Mark (2020) https://www.ancient.eu/Upanishads/ Upanishads, 10 June, 2020.

[11] https://en.wikipedia.org/wiki/Vedas\#- -- Vedas (The page was last updated on $17^{\text {th }}$ January, 2021).

[12] https://en.wikipedia.org/wiki/Ralph T. H. Griffith. Ralph T. H. Griffith (This page was last edited on 30 November 2020.

[13] https://en.wikipedia.org/wiki/Horace_Hayman_Wilson
Horace Hayman Wilson (This page was last edited on 26 December 2020.

[14] https://en.wikipedia.org/wiki/William_Dwight_WhitneyWilliam Dwight Whitney (This page was last edited on 19 December 2020).

[15] https://en.wikipedia.org/wiki/Dayananda_Saraswati-Dayananda saraswati (This page was last edited on 2 January 2021.

[16] https://en.wikipedia.org/wiki/Max_M\%C3\%BCller -Max Muller. This page was last edited on 29 November 2020.

[17] Alex--These-8-western-philosophers-were-influenced-byhinduism https://detechter.com/these-8-western-philosopherswere-influenced-by-hinduism/.

[18] https://en.wikipedia.org/wiki/Himalayas- Himalayas (This page was last edited on 26 December 2020).

[19] Karnick, C. R. (1969) True Identity of 'Soma' Plant - The Famous Ayurvedic Rejuvenating and Longevity Promoting Drug, Quarterly Journal of Crude Drug Research, 9:4, 14731479, DOI: $10.3109 / 13880206909066294$.

[20] Acharya Balkrishna, Rajesh Kumar Mishra, Anupam Srivastava, Bhasker Joshi, Ramakant Marde and Uday Bhan Prajapati (2019) Ancient Indian rishi's (Sages) knowledge of botany and medicinal plants since Vedic period was much older than the period of Theophrastus, A case study who was the actual father of botany? International Journal of Unani and Integrative Medicine. 3: 40-44.

[21] https://en.wikipedia.org/wiki/Sushruta_Samhita Sushruta Samhita - (This page was last edited on 20 December 2020.

[22] https://en.wikipedia.org/wiki/Charaka_Samhita- Charaka Samhita (This page was last edited on 2 December 2020.

[23] Paulo Nuno Martins (2017). The history of the Indian sacred book (Atharva -Veda) and its contribution to the integrative medicine model. Transdisciplinary Journal of Engineering \& Science, 8, 51-59. Doi: 10.22545/2017/00080.

[24] Prasad, P. V. V. (2002) general medicine in atharva Veda with special reference to yaksma (consumption / tuberculosis). Bull. Ind. Inst. Hist. Med. Vol. XXXII, 1 to 14 http://www.ccras.nic.in/sites/default/files/viewpdf/jimh/BIIH M_2002/1\%20to\%2014.pdf.

[25] Mira Roy Family relationships of some plants in the Atharva Veda-162-177. https://insa.nic.in/writereaddata/UpLoadedFiles/IJHS/Vol05 1 _14_MRoy.pdf.

[26] https://www.wisdomlib.org/definition/jangida Jangida: 4 definitions. (Item last updated: 04 August, 2020). 